\section{Refiguring the Subaltern}

\section{Peter D. Thomas'}

Political Theory

$1-24$

(C) The Author(s) 2018

Reprints and permissions: sagepub.com/journalsPermissions.nav DOI: $10.1177 / 0090591718762720$ journals.sagepub.com/home/ptx

@SAGE

\begin{abstract}
The subaltern has frequently been understood as a figure of exclusion ever since it was first highlighted by the early Subaltern Studies collective's creative reading of Antonio Gramsci's carceral writings. In this article, I argue that a contextualist and diachronic study of the development of the notion of subaltern classes throughout Gramsci's full Prison Notebooks reveals new resources for "refiguring" the subaltern. I propose three alternative figures to comprehend specific dimensions of Gramsci's theorizations: the "irrepressible subaltern," the "hegemonic subaltern," and the "citizensubaltern." Far from being exhausted by the eclipse of the conditions it was initially called upon to theorize in Subaltern Studies, such a refigured notion of the subaltern has the potential to cast light both on the contradictory development of political modernity and on contemporary political processes.
\end{abstract}

\title{
Keywords
}

subalternity, hegemony, Gramsci, civil society, political modernity

The subaltern is usually understood today as a figure of exclusion, representing the specular opposite of the citizen. If the citizen is defined by participation in a political community, the subaltern represents a lack of access to institutions of rights and obligations. While citizens are subject to the hegemonic logic of modern sovereignty, the subaltern lies before or beyond it, in some indeterminate zone of affect and habit. Citizenship guarantees inclusion

\footnotetext{
'Department of Social and Political Sciences, Brunel University London, Uxbridge, United Kingdom
}

\section{Corresponding Author:}

Peter D. Thomas, Department of Social and Political Sciences, Brunel University London, Kingston Lane, Uxbridge, UB8 3PH, United Kingdom.

Email: PeterD.Thomas@Brunel.ac.uk 
within structures of representation, in both political and aesthetic senses, at the limits of which subalternity begins. ${ }^{1}$ The subaltern can thus be understood as a variant of those figures of marginality and exclusion that have marked the borders of modern political thought, from Hobbes's multitude, Hegel's Pöbel and Marx's Proletariat, to contemporary formulations such as Rancière's "part that has no part" or Agamben's homo sacer. In this sense, the supposedly unrepresentable subaltern is ultimately represented as the literal incarnation of the principle of exclusion as the foundation of political modernity, and perhaps even of the political as such.

This understanding of the subaltern emerged from the complicated history of development and translation of subaltern studies. Under the leadership of Ranajit Guha, the early Subaltern Studies collective forcefully directed attention to the novelty of the figure of the subaltern in the Prison Notebooks, which had previously been neglected in discussions of Gramsci's thought outside Italy. ${ }^{2}$ In particular, the collective's suggestive if occasional references to the partial English translation of Gramsci's carceral writings emphasized the utility of this figure for the analysis of colonial and postcolonial history in South Asia. ${ }^{3}$ For Guha, writing in the first volume of Subaltern Studies, subalternity referred to "the general attribute of subordination in South Asian society whether this is expressed in terms of class, caste, age, gender and office or in any other way." Conceived as synonymous with "the people," the subalterns constituted "an autonomous domain," signifying "the demographic difference between the total Indian population and all those whom we have described as the 'elite."'5

While Guha's approach strongly influenced the early Subaltern Studies collective's project, particularly in terms of an effective equation of the subaltern with the peasantry, it was arguably Gayatri Spivak's famous intervention "Can the Subaltern Speak?" that instead became the most decisive perspective for the figure's subsequent globalization. Revising a text originally drafted before her encounter with the Subaltern Studies project, Spivak argued that the subaltern was not only deprived of the capacity to speak by the dominant order, but that the subaltern was defined by its exclusion from representation as such, in both political and aesthetic senses. ${ }^{6}$ As an unrepresentable remainder or "limit" of forms of cultural, social, and political domination, "removed from all lines of social mobility,"7 the subaltern thus appeared to be a category suited to analyze and to problematize the experiences of marginalized, oppressed individuals and groups, particularly in colonial and postcolonial contexts.

This approach not only gave rise to what has since become effectively an entire genre of critical writing exploring various dimensions of the subaltern's "incapacity." It also strongly influenced the translation of subaltern studies from South Asian historiography into the literary, sociological, 
anthropological, and theoretical accents that have marked its elaboration in Latin America, Central and East Asia, the Middle East, the USA, and Ireland. ${ }^{8}$ Despite its international success, however, key theorists in the development of the original Subaltern Studies project have questioned the continuing relevance of the figure of the subaltern, or have even suggested its historical exhaustion (particularly in its "classical" formulation as insurgent peasant). Spivak, for instance, argues that developments under neoliberalism since the 1990s have involved a transition to a "new" figure of the subaltern, no longer defined by its removal from social mobility but by the invasive workings of globalization at social, political and biopolitical levels. ${ }^{9}$ Chakrabarty, on the other hand, suggests that the contradictory development of Indian democracy has fundamentally transformed the conditions originally theorized by Guha, while Chatterjee proposes that the subalterns excluded by the colonial and postcolonial order have been superseded by "populations" "governed" in "political society." 10 In a related but distinct way, Pandey argues that the "peasant paradigm" of subaltern studies should be recast in term of the "deliberately paradoxical" figure of the "subaltern citizen," in order to comprehend the traces of subalternity that subsist even within the ongoing expansion of institutions of modern citizenship. ${ }^{11}$

The development of Subaltern Studies was determined from the outset by reference to a partial translation of Gramsci's Prison Notebooks. The research agendas, projects, and critiques produced by the globalization of the figure of the subaltern now effectively constitute their own distinct research paradigm, separate from - and increasingly citing less frequently - the formulations by Gramsci that had initially inspired them. In this article, I aim to suggest that a return to the integral edition of the full Prison Notebooks provides us with a very different perspective on the figure of the subaltern. ${ }^{12}$ In particular, I will argue that a contextualist and diachronic study of the development of the notion of subaltern classes or social groups throughout the Prison Notebooks reveals new resources for considering this figure's both historical and contemporary relevance.

The subaltern for Gramsci is not defined by an experience of exclusion. On the contrary, subaltern social groups are represented in the Prison Notebooks as integrally and actively "included" or integrated into the hegemonic relations of what Gramsci characterizes as the bourgeois "integral state." This integration, however, should not be thought in terms of an incorporation within the modern state-form of elements previously located "outside" it. Rather, inclusion here should be understood in terms of something closer to an active sense of its etymological origins, that is, as an "enclosing." It is the enclosure of subaltern classes and social groups within the relations of the integral state that constitutes them as distinctively modern subaltern social groups. They are conceived not as sociological entities defined by a 
prior history, but as constituted solely within and by the novel relationality of subalternity that characterizes political modernity. Rather than their exclusion or inclusion, therefore, it is more analytically useful to speak of the "constitution" of subaltern social groups. Subalternity in this sense is a function of the process of material constitution of the modern state itself. Far from being unrepresentable, subaltern social groups in the Prison Notebooks are depicted as the product of elaborate representative and self-representative strategies; instead of being unable to speak, Gramsci's historical and cultural analyses emphasize the extent to which the subaltern continually makes its voice heard and its presence felt in contradictory and complex cultural, social and political forms. No exceptional or marginal case, subalternity for Gramsci is all too quotidian and central; it describes the basic structuring conditions of political modernity in all of its contradictory forms. This understanding of the subaltern does not oppose it to the figure of the citizen. Rather, it conceives the subaltern as a figure in which the contradictions of modern citizenship are intensely realized.

The article is divided into three sections. In the first section, I track the emergence of Gramsci's distinctive notion of subalternity in the early phases of the Prison Notebooks. I emphasize the extent to which it was originally formulated not in order to theorize contexts of failed or compromised state formation, but, on the contrary, in order to characterize a political relation that Gramsci regarded as synonymous with the formation of the modern state, including but not limited to western Europe. In the second section, I then consider the reasons for this novel development in Gramsci's vocabulary. I argue that Gramsci's reflections on subaltern classes or social groups were developed in close relation to, and in the same period as, his theory of the modern state as an "integral state." Within this perspective, the analysis of social and political relations of subalternity constitute the defining coordinates of Gramsci's distinctive inheritance of Hegel's notion of "civil society." In the third section, I argue that this reading allows us to "refigure" the subaltern. Rather than a figure of exclusion or marginality, I propose three alternative figures to comprehend specific dimensions of Gramsci's theorizations: the "irrepressible subaltern," the "hegemonic subaltern," and the "citizen-subaltern." In conclusion, I suggest that far from being exhausted, a refigured notion of the subaltern has the potential to cast light both on the contradictory development of political modernity and on contemporary political processes.

\section{Subalternity in the Prison Notebooks}

Explicit terms from the semantic field of subalternity can be found in Gramsci's pre-prison writings, though their occurrence is relatively rare. In 
those cases, we mostly encounter a generic usage of the term, derived from the metaphoric deployment of an originally administrative and military vocabulary that became current in journalistic writing in Italy during the First World War and its aftermath. ${ }^{13}$ Such a generic usage is maintained also in some passages in the Prison Notebooks, particularly in the initial phases of their development in 1929 and early 1930.14 "Subaltern classes" or "subaltern social groups" is not a topic in Gramsci's initial work plan at the beginning of his first Notebook or in letters from this period..$^{15}$ Those plans do, however, include themes that seem to represent a continuation and deepening of Gramsci's theoretical research project immediately prior to imprisonment in 1926, embodied in the unfinished text Some Aspects of the Southern Question [Alcuni temi della quistione meridionale]. This text does indeed include significant themes, such as disaggregation, amorphousness, and a lack of conscious self-direction, that Gramsci much later groups together and systematically develops under the rubric of "subaltern social classes" and related terms; but both the term and concept of "subaltern social classes" do not appear in Some Aspects of the Southern Question. ${ }^{16}$ As Buttigieg has argued, that fact that "history of subaltern social groups" later constitutes the subtitle of one of Gramsci's so-called "special notebooks" (Notebook 25, from 1934-5) suggests that Gramsci himself only slowly became aware of the importance of this topic for his overall project. ${ }^{17}$ If the concept of subalternity is already at work in texts from Gramsci's pre-carceral or even early carceral periods, it does so in a hidden way- "hidden" not only from fascist censors, but also from Gramsci himself.

It is therefore all the more remarkable both how rapidly the theme of subalternity emerges in Gramsci's thought, in the space of a few months in the summer of 1930, and the extent to which these first appearances outline a perspective that remains consistent throughout the Prison Notebooks. The term first appears in the title of a brief note written in early June 1930, "History of the dominant class and history of the subaltern classes" [Storia della classe dominante e storia delle classi subalterne $].{ }^{18}$ Gramsci here outlines some of the fundamental perspectives that remain determining for all his research on subalternity. He argues that

the history of the subaltern classes is necessarily disaggregated and episodic: there is in the activity of these classes a tendency to unification, even if on provisional levels; but it is the less apparent part that only appears when victory is achieved. The subaltern classes suffer the initiative of the dominant class, even when they rebel; they are in a state of alarmed defense. Every trace of autonomous initiative is thus of inestimable value. At any rate, the monograph is the most adequate form for this history, which requires a great accumulation of partial materials. ${ }^{19}$ 
It is not clear precisely why Gramsci adopted this novel vocabulary at this moment. He may have been stimulated by the work of the ancient historian, erstwhile socialist and meridionalista Ettore Ciccotti, which is discussed extensively in the immediately following notes, though Ciccotti does not himself use the term. ${ }^{20}$ In one of these notes, while discussing the limits of Ciccotti's method of historical "analogy," Gramsci formulates a distinction between "old" and "new" subalterns, or between "pre-modern" and "modern" subaltern social classes. ${ }^{21}$ In the ancient and medieval worlds, the "subaltern classes had a separate life, their own institutions," and the state was effectively a " "federation" of classes"; but "the modern state," Gramsci argues

abolishes many autonomies of the subaltern classes - it abolishes the state as a federation of classes - but certain forms of the internal life of the subaltern classes are reborn as parties, trade unions, cultural associations. The modern dictatorship abolishes these forms of class autonomy as well, and it tries hard to incorporate them into the activity of the state: in other words, the centralization of the whole life of the nation in the hands of the dominant class becomes frenetic and all-consuming. ${ }^{22}$

Gramsci's references make clear that he is not thinking in the first instance of failed or deformed state formation, or limiting this perspective to his immediate circumstances, as inmate of a Fascist prison cell ("the modern dictatorship"). Instead, he argues that this reconfiguration of the life of the subaltern classes constitutes a general process in political modernity, the dynamic of which he dates back to at least the French Revolution. Rather than a supposed transformation of "subjects" into "citizens," or the affirmation of principles of popular sovereignty or autonomy, Gramsci instead focuses upon the "enclosure" of the life of the subaltern classes in a process of simultaneous mobilization and domestication. Political modernity is in this view distinguished by the contradictory forms in which "private" energies released on the terrain of consolidating capitalist market relations are immediately overcoded by the extension of "public" "administrative power. ${ }^{23}$ This new form of subalternity, he argues, is qualitatively distinguished from the status of oppressed, marginalized, or excluded social groups in previous social formations.

"History of the subaltern classes," a note from August 1930, is undoubtedly Gramsci's most significant analysis of the variegated and gradated nature of subalternity. ${ }^{24} \mathrm{He}$ begins by restating his observations regarding the disaggregation of subaltern classes, but now formulates this condition in relation to the notion of "civil society." 
The historical unification of the ruling classes is in the state and their history is essentially the history of states and of groups of states. This unity has to be concrete, and thus the result of relations between the state and civil society. For the subaltern classes unification does not occur: their history is intertwined with that of "civil society," it is a disaggregated fraction of it.

He then proceeds to provide an outline of themes for further study, which has been understood as both a methodology for research into the history of subaltern social groups, and also as the fundamental elements of a political strategy for the emergence from subalternity. ${ }^{25}$

It is therefore necessary to study: 1) the objective formation of the subaltern classes through the developments and changes that took place in the economic sphere, the extent of their diffusion and their descent from other classes that preceded them; 2) their passive or active adherence to the dominant political formations; that is, their efforts to influence the programs of these formations with demands of their own; 3 ) the birth of new parties of the ruling class to maintain control of the subaltern classes; 4) the formations of the subaltern classes themselves, formations of a limited and partial character; 5) the political formations that assert the autonomy of the subaltern classes, but within the old framework; 6) the political formations that assert complete autonomy, etc. The list of these phases can be further specified with internal phases or with combinations of different phases. ${ }^{26}$

This note further emphasizes that subalternity should not be regarded as exterior to hegemony, or as its polar opposite. Pointing to the example of the bourgeoisie's development from an originally subaltern position by means of a complicated politics of alliances with other popular and non-aristocratic classes, Gramsci argues that hegemonic relations also occur within and between subaltern classes, as increasingly expansive forms of political autonomy from the existing social order are unevenly asserted by different subaltern groups. It is precisely because hegemony is already at work within subalternity itself, as a condition and consequence of the subaltern classes' disaggregation, that a potential transition from the subaltern to the hegemonic is conceivable.

Having attained to this definition of subaltern classes in the Summer of 1930, Gramsci goes on to discuss themes related to subalternity extensively in his subsequent notebooks, in more than thirty notes written between the Summers of 1930 and 1933 (when a serious crisis of Gramsci's health leads to a significant decline in his productivity, only partially resumed in 1934). On the one hand, "history of subaltern classes" becomes a rubric under which he gathers a wide variety of bibliographical references related primarily to 
the history of the socialist movement. ${ }^{27}$ On the other hand, and more significantly, Gramsci continues to develop the theme of a dialectic between subaltern and hegemonic — or, synonymously, leading [dirigente] —elements of social classes. Thus, in February-March 1932, he argues that

when the subaltern becomes leading and responsible . . the mechanistic conception will sooner or later represent an imminent danger. ... Why? because ... the "subaltern" who . . . yesterday was not responsible because he was "resisting" an extraneous will . . is now responsible, no longer a "resister" but an active agent. But was he ever mere "resistance," mere "thing," mere "nonresponsibility"? Certainly not. That is why the inept futility of mechanical determinism ... must be exposed at all times, without waiting for the subaltern to become leading and responsible. ${ }^{28}$

This emphasis upon the hegemonic constitution of subalternity is continued in Notebook 25, entitled "On the Margins of History," followed by the parenthetical subtitle "(History of Subaltern Social Groups)." Composed in late 1934, Notebook 25 is one of the so-called special "Notebooks of Formia," in which Gramsci, by now in a condition of rapidly deteriorating health, attempts to reorganize his previous notes into thematic groupings. ${ }^{29}$ The notion of subalternity as a form of enclosure of subaltern classes within the political relations of the modern state has by now become so central to Gramsci's perspective that it even overdetermines the revision of notes not originally formulated in these terms. Thus, Notebook 25 begins with the transcription and significant revision of a note from early 1930 (i.e., just prior to the emergence of subalternity in Gramsci's vocabulary) on the curious case of the literally unarmed prophet Davide Lazzaretti, the leader of "tendentially republican" movement in Tuscany in post-Risorgimento Italy that was "bizarrely mixed" with religious and prophetic elements. ${ }^{30}$ Gramsci is particularly concerned to emphasize the "modernity" of Lazzaretti's religious republicanism, drawing attention to the emergence of this only seemingly "spontaneous" movement in a period when the Catholic Church's abstention from official politics in the post-Risorgimento state, alongside popular delusions in a newly installed government of the left, had released subaltern energies from containment within established political structures. ${ }^{31}$ Similarly, in another $\mathrm{C}$ text from this period, the abolition of the "many autonomies of the subaltern classes" of which Gramsci spoke in 1930 is reformulated and specified in terms of their "subordination to the active hegemony of the leading and dominant group." 32 Subaltern social classes are thus represented not as excluded from the modern state, nor as merely oppressed or subjugated by it. Rather, they are fundamentally transformed and reconstituted by its expansive logic, mobilized to 
participate in the projects of the dominant group in contradictory and frequently passive forms.

From the margins of Gramsci's research plans at the beginning of his imprisonment, the theme of subalternity thus steadily became one of the most consistent lines of research both during and beyond the most productive phase of his carceral writings. What were the reasons for this novel conceptual development?

\section{Subalterns in the "Integral State"}

My thesis is that the significance of this developing research theme can only be integrally understood by attending to the context in which it emerges and is developed, or in other words, its temporal relation to other themes in the Prison Notebooks project. For Gramsci's research on subaltern social groups is initiated in the same period (mid-1930) in which he begins to develop his central concepts of the "integral state" and "passive revolution." The three concepts function as dialectical counterpoints to each other, each complementing and extending the lines of research pursued under the headings of the others. On the one hand, subalternity is one of the themes by means of which Gramsci clarifies for himself the political significance of the concepts of the integral state and passive revolution; that is, subalternity is conceived as the concrete political relation that is produced by the historical emergence of the bourgeois integral state. On the other hand, the concept of the modern state as an "integral" state, particularly when complemented by Gramsci's parallel development of the notion of passive revolution as a "logic" of the integral state's development in the late nineteenth and early twentieth centuries, is one of the ways in which he clarifies the structuring dynamics of subalternity. ${ }^{33}$

Against what were effectively the neo-Kantian revisions of Marx's state theory by dominant currents in both the Second and Third Internationals, the Prison Notebooks undertake a critical return to the Hegelian theory of the state. Like Hegel (and in opposition to the various caricatures of the state theory of the Philosophy of Right, within and outside the Marxist tradition), Gramsci insists upon the mutually constitutive relations between "civil society" and what he characterizes as "political society" or "state." 34 "The general notion of the state," he argues in mid-1931,

includes elements which need to be referred back to the notion of civil society (in the sense that one might say that the State $=$ political society + civil society, in other words hegemony armored with coercion). ${ }^{35}$ 
Civil society and political society here are not conceived as separate geographical or institutional terrains, or as "autonomous domains" (in Guha's sense), but as forms of imbricated socio-political relationality. ${ }^{36}$ They are relations of integration that are articulated in varying degrees of extension and intensity in different contexts, from the organizing and directive instances summarized in the notion of political society, to the associative, externally directed practices and only seemingly "non-political" dimensions of social life comprehended in the notion of civil society. Rather than coming before, after or alongside the state, civil society is understood by Gramsci as "enclosed" within it, or more precisely, as a constitutive element of it. Civil society, that is, is not opposed to the state, in an external relationship that would make possible the "assimilation" of the former by the latter (or civil society's "non-assimilation," in the case of the "colonial state"). ${ }^{37}$ It is instead conceived as a politically overdetermined system for the regulation of needs, associations and conflicts, or, in Hegelian terms, as an "external state" [äußeren Staat], the state as the Understanding conceives it [Not- und Verstandesstaat]. ${ }^{38}$ Civil society is thus not characterized by "consent" and opposed to the "coercion" of the state, or conceived as a terrain of equality and formalized rights and responsibilities. More expansively, it includes all those practices in which the state's rationality is realized and affirmed, frequently unknowingly and often in associative or communal forms that may appear to be autonomous from or even opposed to it. In Hegelian terms, "the entire complex of practical and theoretical activities with which the ruling class" manages to secure its dominance includes for Gramsci not merely the Polizei and the corporations, but also the revolts of the Pöbel and their pacification. ${ }^{39}$ The type of hegemony characteristic of the passive revolutionary phase of the integral state's development is conceived as a synthesis of these associative and organizing instances, of civil and political society. Each instance is essential to the relationship, but it is a synthesis that occurs on the terms of and is directed by only one of those relations, namely, that of the existing political society.

As Francioni has noted, the central note in the development of this novel conception, constituting nothing short of a sea-change that redefines Gramsci's entire carceral project, dates from October 1930-precisely the period in which Gramsci is elaborating his reflections on subalternity. ${ }^{40}$ This note represents a point of no return: the notion of a dialectical "identity-distinction between civil society and political society" enables Gramsci to theorize political modernity beyond the exclusionary figures that have dominated modern political thought since at least Hobbes. ${ }^{41}$ The decisive feature of this development for comprehending the specificity of modern subaltern classes is that they remain entrapped within the relationality proper to civil society 
conceived in this sense. Their history, as Gramsci argues in 1930, "is intertwined with that of "civil society,' it is a disaggregated fraction of it." 42 They are unable, qua subaltern social groups, to assume the self-directive and directing capacities embodied in the form of political society. In late 1934, Gramsci adds in the revised $\mathrm{C}$ text that "the subaltern classes, by definition, are not unified and cannot unify themselves until they become the "state."'43 Civil society, far from being a terrain of freedom before or beyond the state, is thus depicted as a mode of relationality characteristic of the disaggregated subalterns; it is a form of the "performance" of subalternity, to use a concept promoted by Judith Butler. ${ }^{44}$ The subaltern social groups are continually fractured by the interventions of the political society that constitutes them as the subaltern "raw material" for its directive operations. Rather than outside of or opposed to the hegemonic, the subaltern in this sense is integrally and immanently related to it, as simultaneously the presupposition and the product of its operations. In short, far from repressing and excluding subalterns, political modernity, according to Gramsci, introduces a new form of relationality that mobilizes them as integral elements in an expansive system of social and political power.

\section{Refigurations of the Subaltern}

The study of the emergence of the semantic field of subalternity in the Prison Notebooks suggests that Gramsci's concepts may have a continuing relevance beyond the exhaustion of the paradigms associated with "classical" subaltern studies and its international diffusion. In particular, it suggests that the subaltern might be "refigured" in order to represent not a residue of the past or an exhausted perspective, but a mode of comprehending contemporary and ongoing political processes. I propose here three such refigurations, each comprehending specific dimensions of Gramsci's theorizations: the "irrepressible subaltern," the "hegemonic subaltern," and the "citizen-subaltern."

\section{The Irrepressible Subaltern}

The conception of subalternity in the Prison Notebooks is radically different from the widely diffused notion that the subaltern is a figure of undifferentiated destitution, consigned to a zone beyond expressive capacity or purposive political agency. Spivak's influential text "Can the Subaltern Speak?" undoubtedly laid the foundations for this approach. Originally written as reflection on debates regarding the status of intellectuals' politics, without reference to the subaltern in either Subaltern Studies or Gramsci, the later prominent insertion of this figure in the essay's title has led to its themes 
assuming almost paradigmatic status in wider discussion of subalternity. Spivak's subsequent interventions have reinforced this general tendency of defining the subaltern primarily in terms of incapacity. In some of her more provocative formulations, for instance, the subaltern becomes an almost mystical concept, in a Wittgensteinian sense: the subaltern not only cannot speak, but is also that figure of whom one should not speak, lest one falls into the trap of speaking for the subaltern and thus dominating it. In Spivak's words, "If the subaltern can speak then, thank God, the subaltern is not a subaltern any more." ${ }^{45}$ Here the subaltern is represented, paradoxically, as that which is not representable in any given order; the entrance into (self-) representation is immediately the exit from subalternity.

For Gramsci, on the other hand, subaltern social groups are continually expressive, albeit in ways which are not easily comprehended within the existing political or intellectual orders - or even by themselves in the initial phases of their rebellions. Gramsci's example of Lazzaretti's propheticrepublican movement, for instance, is composed of layer upon layer of subaltern expressions and representative containments. On the one hand, this note is framed by considerations of the way in which Italian social commentators and theorists, including Bulferetti, Verga, Lombroso and Barzellotti, had represented this and other similar movements in post-Risorgimento Italy in terms of a "pathological biography," giving "restrictive, individual, folkloric explanations" of movements that called for broader contextual and political analysis. ${ }^{46}$ On the other hand, Gramsci argues that representative dynamics are discernible within Lazzaretti's movement itself. One of the reasons for Lazzaretti's popular appeal, he argues, was that Lazzaretti reformulated peasant discontent with previous manifestations of republicanism in Tuscany, particularly in 1848 , in a prophetic direction. Gramsci understands this not as a negation of subalternity, but as a form of attempted self-representation in which the movement's subaltern status was performed, even and especially in the attempt to overcome it.

The parenthetical subtitle of Notebook 25 is perhaps the most telling indication of the extent to which a dialectic between expression and representation is inscribed within Gramsci's conception of subalternity. Subaltern classes or social groups are "on the margins of history," that is, "history" conceived in the sense of historiography, as a text written almost invariably by the victors. ${ }^{47}$ This does not mean, however, that they are "without" or "outside" history, in the sense of the real historical events that the dominant forms of historiography seek to narrativize and by so doing to domesticate. Subalterns are fully present actors on the stage of history, though reduced to minor and fleeting roles in the official script. Extra- or para-discursive forms of subaltern expression jostle alongside inchoate and often discordant 
attempts to develop forms of self-representation. ${ }^{48}$ It is the role of what Gramsci calls the "integral historian" to recover and valorize the full range of these forms of expression within and beyond the dominant narratives. ${ }^{49}$

Furthermore, rather than an amorphous mass of the indifferently oppressed, Gramsci's conception emphasizes the varying degrees of subalternity within the subaltern social groups. There are many subalterns within the subaltern relationality of civil society, structured by their relation to the organizing instances or relations of political society. As Green and Crehan have noted, Gramsci's conception of subalternity is not limited to class understood in an economistic sense, but includes a wider range of relations, including gender, ethnicity, and regionality. ${ }^{50}$ Just as significantly, the fact that they are actively and differentially incorporated in historically specific systems of hegemonic power, in forms of passive citizenship just as much as by practices of pacification, also means that there are different potential stages in the emergence from subalternity. There is no Rubicon lying between subalternity and hegemony, just as civil society and political society are not conceived as spatially distinct zones. Rather, there are degrees of subalternity, and degrees of emergence from it, ranging from inchoate rebellion, co-optation, partial or merely asserted autonomy, to complete autonomy. Were there no degrees of subalternity, were civil society a terrain of total domination instead of a continually renewed hegemonic relation of subordination, hegemony, as the emergence of capacities for self-direction and leadership of previously subaltern social groups, would not be a realistic political strategy.

\section{The Hegemonic Subaltern}

The emphasis in the early volumes of Subaltern Studies upon the "autonomous domain" of the subalterns or the people has frequently been interpreted to imply an externality of the subaltern to the hegemonic. Guha's analysis of the condition of "dominance without hegemony" in South Asia, for instance, depicted a socio-political formation composed of "subjects," "vast areas in the life and consciousness" of whom "were never integrated into [the Indian bourgeoisie's] hegemony." In other words, it was not a society populated by the "citizens" that Guha held to be the "normal" inhabitants of political modernity and its hegemonic constitution in Western Europe. ${ }^{51}$ Chatterjee has extended this perspective to argue that the failure of the Indian bourgeoisie to stabilize a "normal" hegemonic order had left the majority of the population in a perennial hegemonic "outside," first in the form of the subalternity of the insurgent peasant in colonial times, and more recently in the form of the populations subjected to a logic of governmentality in the "political society" of the post-colonial state (defined by Chatterjee in an antinomic rather 
than dialectical relation to civil society, which he conceives as the terrain of "rights-bearing citizens"). ${ }^{52}$ Later inheritors of this approach have emphasized in more strongly normative terms the opposition of the subaltern and the hegemonic. In a formulation representative of an important tendency in Latin American subaltern studies, for example, Alberto Moreiras argues that the subaltern should be understood as a "perspective from the constitutive outside of hegemony," or as "the remainder of the hegemonic relation." 53

In the Prison Notebooks, however, the subaltern is not opposed to the hegemonic, but constitutes its necessary complement. The type of subalternity that interests Gramsci is already "enclosed" or constituted within the hegemonic relations of the passive revolutionary processes condensed in the bourgeois integral state. These subaltern classes or social groups do not simply exist as such, in a supposedly "natural" or "pre-political" (as opposed to "historical" or "political") dimension before or beyond the state, as Guha rightly insisted. Precisely insofar as they are both fully "modern" and fully "political," however, subaltern classes or social groups, whether in the metropolitan "centers" or their colonial "peripheries," participate in hegemonic relations in varying forms. Subalternity, that is, constitutes a general dynamic in political modernity, even and especially within the different conditions and contexts of its development. ${ }^{54}$ The preponderance of coercion over persuasion does not indicate the absence or diminution of hegemonic relations, or what Guha characterized as the "dominance without hegemony" of the "nonhegemonic" South Asian "colonial state." ${ }^{55}$ Rather, it points to the differential articulation of those hegemonic relations, to the shifting balance between mobilization and domestication, between private and public initiatives of state power, in different concrete contexts. The notion of passive revolution, in its complex development and implications, registers precisely this potential for such a form of "hegemony without hegemony," whether produced by a crisis of the "normal" exercise of hegemony on the "classic terrain" of the parliamentary regime in western Europe, ${ }^{56}$ or the supposed "failures" of revolutionary or national liberation movements to establish it elsewhere. The type of modern subalternity on which Gramsci's analyses focus is both an index and expression of the efficacy of such passive revolutionary processes.

This understanding of the hegemonic constitution of subalternity also has implications for understanding the hegemonic constitution of the ruling classes. Just as the subalterns are not merely the excluded, so too are the ruling classes not simply oppressors or dominators. In late 1934, in Notebook 25, Gramsci transcribes the note from August 1930 in which he had first linked the fate of subaltern classes to civil society. He introduces some significant specifications in his revisions that emphasize that the formation of 
the ruling classes is also determined by the hegemonic relations within the integral state. He argues that

the historical unity of the ruling classes occurs in the state and their story is essentially the history of states and of groups of states. But we shouldn't think that such unity is purely juridical and political, even if this form of unity has its importance, and not merely a formal importance: the fundamental historical unity, in its concrete nature, is the result of the organic relations between state or political society and "civil society." ${ }^{57}$

Insofar as the historical unity of the ruling classes results from the organic relations between political society and civil society, such unity presupposes just as much as it imposes the production of subalternity. Ruling classes in political modernity need to produce - and to reproduce continually - subaltern social groups in order to become and to maintain themselves as ruling classes. Whether in the extreme forms of fascist dictatorship or colonial administration, or in the seemingly more benign forms of liberal representative regimes with their systems of political elites and passive citizenries, the need for the continual production and reproduction of subaltern social groups constitutes a fragile and tenuous basis of enduring political power. It remains always dependent upon the ongoing subjugation of its interpellated antagonist, or upon the hegemonic relations of force that constitute it in both a material and formal sense. It is precisely here, in the midst of a hegemonic relationship, constitutively open to contestation, that the potential political power of the subaltern lies.

\section{The Citizen-Subaltern}

One of the fundamental perspectives of early subaltern studies was a distinction between "subjecthood" and "citizenship." While the latter was conceived as hegemonically constituted in the imperial centers, the former was the condition of the subalterns in their colonial peripheries. Such an exclusion from full participation in the normal or even normative institutions of political modernity that has been held to continue, in the case of the Indian Republic, long into the postcolonial period. ${ }^{58}$ In one of the most innovative attempts to update or "to sublate" the legacy of Subaltern Studies after the exhaustion of its classical "peasant paradigm," Pandey has urged the adoption of the "deliberately paradoxical . . . category of the subaltern citizen." ${ }^{59}$ These "subaltern citizens" are those "for whom the promise of freedom, of equal opportunity and an equal share in the fruits of modernity, has long been constantly renewed, and constantly deferred," 60 those "who have been granted the status 
of citizen (rights-holders, inhabitants, subjects of the state) without becoming quite "mainstream." "61 In a dual move, the "traditional" subaltern is thus reconceived, on the one hand, as a "potential citizen," 62 a potential now still only partially fulfilled for some social groups; and on the other, subalternity comes to be seen as an enduring "trace" or latent threat of exclusion, even and perhaps especially within the achievement of citizenship. Subalternization, conceived in terms of "minoritarization," 63 continues to represent a primary experience of exclusion, oppression, and marginalization. It both precedes (historically and logically) the affirmation of citizenship, and continuously threatens to re-emerge within it, frustrating the full realization of citizenship's promises.

In the Prison Notebooks, however, the type of modern subalternity generated within the hegemonic dynamics between civil society and political society in the integral state does not precede citizenship or subsist within it as trace or threat. Citizenship is conceived not as a supplement or corrective to the subaltern's "otherness" but as one of the forms of the political expression of subalternity. In other words, citizenship and subalternity in the Prison Notebooks are in a relationship of simultaneous co-constitution. The two concepts can be regarded as different vocabularies for describing (and in so doing validating or challenging) the same historical process: on the one hand, the narrative of political modernity as the consolidation of juridical forms guaranteeing individual rights and responsibilities within a homogenous political community; on the other hand, the history of the constitution of hegemonic relations of subordination between classes and groups, with dominance by one group in political society depriving other groups of the capacity for self-direction and autonomous political initiative in civil society. Conceived as two sides of the same coin, the two vocabularies can thus be seen as developing in parallel, reinforcing or subverting each other. Rather than the "citizen subaltern" or the "subaltern citizen," in which one of the terms qualifies the other, I argue that this relation is more adequately characterized by the figure of the coterminous "citizen-subaltern," or "citizen sive subaltern." Gramsci's theory of subalternity can therefore be regarded as an attempt to theorize the constitutive relationship between freedom and unfreedom in political modernity that Balibar has more recently proposed to comprehend with the figure of the "citizen subject." 64

Thus, just as subaltern classes or social groups are never completely deprived of expressive or representative capacities, and just as subalternity is not exterior to hegemony but a product of it, so is subalternity not a relation of exclusion from citizenship, but rather, one of the forms of its realization. This does not mean, however, that the relationship between subalternity and citizenship should be thought in the specular terms of an inclusion of what 
was originally excluded, or even as the type of "inclusive exclusion" theorized by Agamben under the heading of the "relation of exception." For Agamben, "the juridico-political order has the structure of an inclusion of what is simultaneously pushed outside," and the "relation of exception" is the "extreme form of relation by which something is included solely through its exclusion." 65 For Gramsci, on the contrary, it is not such an exclusion (whether conceived in the benign forms of marginalization or minoritorization, or the extreme forms of expulsion) that encloses the subalterns within the integral state. Rather, it is their active mobilization within hegemonic relations in civil society, especially in the dynamic of passive revolutionary processes, from "transformist" integration of them into other social groups' political organizations, to the constitution of their own economic corporative associations and even partially autonomous political organizations. This enclosure is constitutive and productive of subaltern classes and social groups. "The end" of subalternity is conceived not in terms of an exit from this condition but as the internal transformation of the hegemonic relations that structure it.

\section{Conclusion}

One of the strongest claims of the early Subaltern Studies project was the insistence that subaltern classes and social groups should be understood not as a residue of the past, but as fully modern phenomena. With an emphasis upon the subaltern as insurgent peasant, this project aimed to recover a tradition of resistance and rebellion that had hitherto been obscured, not only in colonial and postcolonial contexts, but globally, insofar as the troubling questions that the experience of colonialism posed to political modernity's claims to universalism had been repressed or ignored. On this basis, the subaltern appeared as a figure with a relevance potentially much broader than the field of South Asian history, as evidenced by its development into a transnational paradigm of historical writing and social scientific and cultural reflection. Ironically, however, subsequent developments of the field have suggested that the figure of the subaltern studied in the early volumes of Subaltern Studies has been progressively eclipsed or outdated by more recent political processes, particularly the impact of neoliberal economic policies and the rise of new political rationalities.

In this context, a return to the texts that provided initial inspiration for Subaltern Studies in Gramsci's Prison Notebooks offers resources for refiguring the subaltern as a "perspective" not confined to particular periods in past history, ${ }^{66}$ or regarded as relevant only to contexts of supposedly "deformed" or "non-normative" state formation. Rather, a study of Gramsci's 
integral development of this notion reveals a much richer field of reflection on the contradictions and forms of political modernity than became apparent during the first season of engagement with his texts. Subalternity for Gramsci is an experience of marginality, in terms of the subalterns' relations to the centers of political power, but it is not a marginal experience, in terms of the political relations and forms to which the majority of the inhabitants of modern political communities are subjected, in the West and North just as much as the East and South. The Prison Notebooks provide a general characterization of political modernity as a process of subalternization. It is a process in which the disaggregation of subaltern classes and social groups in civil society, or associative forms, constitutes them as the objects of the directive instances of political society, or of instances of political organization and administration.

Far from being exhausted by recent political transformations, this expansive understanding of subalternity seems particularly well placed to comprehend significant developments in a wide variety of contemporary political contexts. For example, Gramsci's emphasis upon the irrepressibility of the subaltern, continually engaged in struggle, has been used to rethink the consequences of the extension of biopolitical and governmental logics in contemporary India. As Nilsen and Roy argue, rather than the negation of an "autonomous domain" of subaltern politics, these developments can be productively analyzed in terms of transformed "entanglements" between civil and political societies, which have been both shaped by subaltern resistance, and have helped to produce new forms of subaltern agency. ${ }^{67}$ Similarly, the notion of subalternity as a hegemonic relation, constitutive not only of subaltern social classes and groups but also of the ruling classes qua "subalternizers," can help to understand both the flood and ebb of the "pink tide" of "progressive" governments in Latin America in the early twenty-first century. As Massimo Modonesi argues, the "pacification" of popular movements in Latin America in recent years might be understood in terms of a process of "re-subalternization," or of the ways in which subaltern rebellions have been compromised by longer-term transformist and passive revolutionary strategies ${ }^{68}$ In another context, Gramsci's analysis of subalternity and citizenship as co-constitutive rather than opposed can also provide a critical perspective on discussions of an "undoing" of democracy by neoliberal rationality that has been argued to characterize politics in the "Euro-Atlantic world" over the last three decades. ${ }^{69}$ Rather than a recent and conjunctural negation of the promises of inclusion within democratic citizenship, Gramsci's theorization suggests that such processes have emerged from longer-term, structural conditions of subalternization inscribed within the general dynamic of political 
modernity, even and especially when it is realized in the contradictory forms of citizenship.

Refiguring the subaltern as irrepressible, hegemonic, and synonymous with the figure of the citizen thus not only constitutes an act of recovery of a significant critical tradition in the history of twentieth-century social and political thought. It can also be understood as a critical perspective onto some of the central debates in contemporary political theory in an international perspective. Ultimately, it offers to initiate a new phase of subaltern studies "beyond Subaltern Studies," a type of subaltern studies that would be both global and contemporary, capable of inheriting the project of reading archives of dominant historiography against the grain, and of intervening into the struggles of the present, in "postcolonial" and "metropolitan" realities alike.

\section{Acknowledgments}

Previous versions of this text were presented at seminars and conferences at the Ghilarza Summer School-Scuola internazionale di studi gramsciani, the University of Sydney, King's College London, the University of Tampere, Oxford Brookes University, and the Institute for Advanced Study, Princeton. I am grateful to participants at those events for their critical engagement with my arguments. I would also like to thank Sara R. Farris, Marcus Green, Alf Gunvald Nilsen, Cosimo Zene, and three anonymous readers for this journal for helpful comments and criticisms.

\section{Declaration of Conflicting Interests}

The author(s) declared no potential conflicts of interest with respect to the research, authorship, and/or publication of this article.

\section{Funding}

The author(s) disclosed receipt of the following financial support for the research, authorship, and/or publication of this article: Research for this article was conducted while a member of the School of Social Science at the Institute for Advanced Study, Princeton

\section{ORCID iD}

Peter D. Thomas (D) https://orcid.org/0000-0002-7906-196X

\section{Notes}

1. For variants of each of these claims, see Partha Chatterjee, The Politics of the Governed: Reflections on Popular Politics in Most of the World (New York: Columbia University Press, 2004); Jon Beasley-Murray, Posthegemony: Political Theory and Latin America (Minneapolis: University of Minnesota Press, 2010); 
Gayatri Chakravorty Spivak, "Can the Subaltern Speak?," in Marxism and the Interpretation of Culture, ed. C. Nelson and L. Grossberg (Urbana: University of Illinois Press, 1998).

2. The key contributions to the Italian discussion of the subaltern in the late $1940 \mathrm{~s}$ and early 1950s are collected in Carla Pasquinelli, ed., Antropologia culturale e questione meridionale. Ernesto De Martino e il dibattito sul mondo popolare subalterno negli anni 1948-1955 (Florence: La Nuova Italia Editrice, 1977).

3. Antonio Gramsci, Selections from the Prison Notebooks, ed. and trans. Quintin Hoare and Geoffrey Nowell-Smith (New York: International Publishers, 1971). With the exception of a brief citation in Guha's "Preface" to Subaltern Studies $I$, direct textual references to Gramsci, and particularly to his characterization of subalternity, are surprisingly rare in the early volumes of Subaltern Studies.

4. Ranajit Guha, "Preface," in Subaltern Studies I, Writings on South Asian History and Society (New Delhi: Oxford University Press, 1982), vii.

5. Ranajit Guha, "On Some Aspects of the Historiography of Colonial India," in Subaltern Studies I, 4, 8.

6. An account of the various iterations of this influential text is provided in Rosalind Morris, ed., Can the Subaltern Speak: Reflections on the History of an Idea (New York: Columbia University Press, 2010).

7. Gayatri Chakravorty Spivak, In Other Worlds: Essays in Cultural Politics (New York: Routledge, 2012), 207; Gayatri Chakravorty Spivak, "Scattered Speculations on the Subaltern and the Popular," Postcolonial Studies 8, no. 4 (2005): 475.

8. Among the numerous attempts to translate subaltern studies into other national, linguistic, and cultural contexts, see David Lloyd, Anomalous States: Irish Writing and the Post-colonial Moment (Durham, NC: Duke University Press, 1993); Florencia E. Mallon, Peasant and Nation. The Making of Postcolonial Mexico and Peru (Berkley: University of California Press, 1995); John Beverley, Subalternity and Representation (Durham, NC: Duke University Press, 1999); Ileana Rodríguez and María Milagros López, ed., The Latin American Subaltern Studies Reader (Durham, NC: Duke University Press, 2001); Touraj Atabaki, ed., The State and the Subaltern: Modernization, Society and State in Turkey and Iran (London: Tauris, 2008); Stephanie Cronin, ed., Subalterns and Social Protest: History from below in the Middle East and North Africa (New York: Routledge, 2008). For reflections on the original Subaltern Studies collective's initiatives, see Dipesh Chakrabarty, Habitations of Modernity (Chicago: University of Chicago Press, 2002), 3-19. For overviews of the field's international development, see Vinayak Chaturvedi, ed., Mapping Subaltern Studies and the Postcolonial (London: Verso, 2000); David Ludden, ed., Reading Subaltern Studies: Critical History, Contested Meaning and the Globalization of South Asia (London: Anthem Press, 2001).

9. Gayatri Chakravorty Spivak, "Discussion: An Afterword on the New Subaltern," in Subaltern Studies XI: Community, Gender and Violence, ed. Partha Chatterjee and Pradeep Jeganathan (New Delhi: Permanent Black, 2000), 305-34. Spivak 
has subsequently extended this argument, focusing in particular on the "new forms of subalternization" represented by the figure of a "new gendered subaltern"; see "Interview with Gayatri Chakravorty Spivak," in The Postcolonial Gramsci, ed. Neelam Srivastava and Baidik Bhattacharya (New York: Routledge, 2012), 221-31.

10. Dipesh Chakrabarty, "Subaltern Studies in Retrospect and Reminiscence," South Asia: Journal of South Asian Studies 38, no. 1 (2005): 10-18; Partha Chatterjee, “After Subaltern Studies," Economic \& Political Weekly XLVII, no. 35 (2012): 44-49.

11. Gyanendra Pandey, "The Subaltern as Subaltern Citizen," Economic \& Political Weekly 41, no. 46 (2006): 4735-41.

12. References to Gramsci's Prison Notebooks will be given according to the Italian critical edition of the Quaderni del carcere, ed. Valentino Gerratana (Turin: Einaudi, 1975), following the internationally established standard of notebook number $(Q)$, number of note $(\S)$, and page number. The English translation of this edition by Joseph A. Buttigieg remains a work in progress, currently including Gramsci's first eight notebooks (New York: Columbia University Press, 1992, 1996, 2007). Dates of individual notes are given according to the chronology established in Gianni Francioni, L'officina gramsciana. Ipotesi sulla struttura dei "Quaderni del carcere" (Naples: Bibliopolis, 1984) and the revisions contained in the appendix to Giuseppe Cospito, "Verso l'edizione critica e integrale dei «Quaderni del carcere»," Studi storici LII: 4 (2011), 896-904. “A texts” refer to Gramsci's first drafts; "C texts" to revised notes; while "B texts" exist in a single version.

13. Guido Liguori, "Subalterno e subalterni nei 'Quaderni del carcere,'” International Gramsci Journal 2, no. 1 (2016): 89-125; Guido Liguori, "Conceptions of Subalternity in Gramsci," in Antonio Gramsci, ed. Mark McNally (Houndmills, UK: Palgrave Macmillan, 2015).

14. See, e.g., $Q 1, \S 43,37$; $\S 48,60$; and $\S 54,67$, all written in February-March 1930.

15. See Gianni Francioni and Fabio Frosini, "Nota introduttiva a Quaderno 25," Quaderni del carcere. Edizione anastatica dei manoscritti, vol. 18, ed. Gianni Francioni (Rome-Cagliari: Biblioteca Treccani-L’Unione sarda, 2009).

16. On the basis of this textual evidence, I thus disagree with Spivak's repeated claim that Some Aspects of the Southern Question is the most significant texts for understanding Gramsci's conception of subalternity, in "Can the Subaltern Speak?," 283; and "Scattered speculations on the subaltern and the popular," 475.

17. Joseph Buttigieg, "Subalterno, subalterni," in Dizionario gramsciano 19261937, ed. Guido Liguori and Pasquale Voza (Rome: Carocci, 2009), 826.

18. $Q 3, \S 14,299-300$. This note is later transcribed in 1934, with significant revisions, under the title "Methodological criteria": $Q 25, \S 2,2283-84$.

19. Q 3, §14, 299-300.

20. In particular, Gramsci focused on a chapter in Ciccotti's Confronti storici (1929), previously published in the Rivista d'Italia as "Elementi di 'verità' e di 'certezza' nella tradizione storica." 
21. $Q 3, \S 18,302-3$ (June 1930); later transcribed in $Q 25, \S 4,2287$, which also includes elements of $Q 3, \S 16,301-2$.

22. $Q 3, \S 18,303$. The notion of a "federation of classes" emphasizes the relative institutional autonomy of popular or subaltern classes before the consolidation of the modern state. Political modernity for Gramsci, on the other hand, is characterized not simply by the abolition of these autonomies, but by their restructuring into forms of state mobilization and control, or what Gramsci will come to characterize as the paradigmatic form of bourgeois hegemony.

23. $Q 1, \S 47,56-58 ; Q 1, \S 48,58-64$ (February-March 1930); $Q$ 6, $\S 10,691$ (November-December 1930).

24. $Q 3 \S 90,372-73$, later transcribed in $Q 25, \S 5,2287-89$.

25. Ranajit Guha, "Preface," vii; Marcus Green, "Gramsci Cannot Speak: Presentations and Interpretations of Gramsci's Concept of the Subaltern," Rethinking Marxism 14, no. 3 (2002): 1-24.

26. $Q 3 \S 90,372-73$.

27. E.g., $Q 4$, $\$ 59,505$ (November 1930); $Q$ 6, $§ 158,812-13$ (October 1931); $Q 7$, $\S 70,907$ (December 1931); $Q$ 8, §66, 980; $Q$ 8, §70, 982; $Q$ 8, §127, 1017-18 (February-April 1932); Q 9, §4, 1099 (April-May 1932); Q 15, §28, 1783 (May 1933). For an analysis of these notes, see Guido Liguori, "Subalterno e subalterni nei 'Quaderni del carcere."'

28. $Q 8, \S 205,1064$. See also $Q 8, \S 153,1033$ (April 1932) and $Q 10 \mathrm{II}, \S 41$ xii, 1320 (August-December 1932).

29. On the different phases of Gramsci's work, see Gianni Francioni, "Come lavorava Gramsci," Quaderni del carcere. Edizione anastatica dei manoscritti, volume 1, ed. Gianni Francioni (Rome-Cagliari: Biblioteca Treccani-L’Unione sarda, 2009) and Gianni Francioni, "Un labirinto di carta (Introduzione alla filologia gramsciana)," International Gramsci Journal 2, no. 1 (2016): 7-48.

30. $Q 3$ \12, 297-99 (May 1930); Q 25, §1, 2279-83 (July-August 1934). Gramsci refers to him as both "Davide" and "David Lazzaretti."

31. $Q 25, \S 1,2280$. See Hobsbawn's very different analysis of this subaltern revolt as "pre-political" and as a "survival of a medieval millenarian heresy" in Primitive Rebels: Studies in Archaic Forms of Social Movements in the 19th and 20th Century (New York: Norton, 1959), 65.

32. $Q 25, \S 4,2287$. See Fabio Frosini, "Reformation, Renaissance and the State: The Hegemonic Fabric of Modern Sovereignty," Journal of Romance Language Studies 12, no. 3 (2012): 71-75.

33. See Pasquale Voza, "Rivoluzione passiva," in Le parole di Gramsci: per un lessico dei "Quaderni del carcere," ed. Fabio Frosini and Guido Liguori (Rome: Carocci, 2004).

34. $Q 1, \S 47,56-58$ (February-March 1930); $Q$ 6, §24, $703-4$ (December 1930); $Q 8, \S 187,1054$ (December 1931). On the development of Gramsci's state theory, see Peter D. Thomas, The Gramscian Moment: Philosophy, Hegemony and Marxism (Leiden: Brill, 2009), 137-48, 173-89.

35. $Q 6, \S 88,763-64$. 
36. For an analysis of the specificity of these terms, see Jacques Texier, "Società civile," and Guido Liguori, "Società politica," Dizionario gramsciano 19261937, 769-73.

37. For an example of the latter argument, see Ranajit Guha, Dominance without Hegemony: History and Power in Colonial India (Oxford: Oxford University Press, 1998), xii.

38. Georg Wilhelm Friedrich Hegel, Grundlinien der Philosophie des Rechts (Frankfurt: Suhrkamp, 1970), §183.

39. $Q 15, \S 10,1765$ (March 1933); cf. Hegel, Grundlinien der Philosophie des Rechts, $\$ 244$.

40. $Q 4, \S 38,455-65$. See Francioni, L'officina gramsciana, 196.

41. $Q 8, \S 142,1028$ (April 1932).

42. $Q 3, \S 90,372$.

43. $Q 25, \S 5,2288$.

44. Judith Butler, Gender Trouble: Feminism and the Subversion of Identity (New York: Routledge, 1990).

45. Gayatri Chakravorty Spivak, The Postcolonial Critic: Interviews, Strategies, Dialogues (New York: Routledge, 1990), 158.

46. $Q 25, \S 1,2279-80$.

47. $Q 25,2277$.

48. On extra-discursive forms of subaltern expression, see Kevin Olsen, "Epistemologies of Rebellion: The Tricolor Cockade and the Problem of Subaltern Speech," Political Theory 43, no. 6 (2015): 730-52.

49. $Q 25, \S 2,2284$.

50. Kate Crehan, Gramsci's Common Sense (Durham, NC: Duke University Press, 2016); Marcus Green, "Rethinking the Subaltern and the Question of Censorship in Gramsci's Prison Notebooks," Postcolonial Studies 14, no. 4 (2011): 387-404.

51. Ranajit Guha, "On Some Aspects of the Historiography of Colonial India," 5-6; Ranajit Guha, The Small Voice of History. Collected Essays (Ranikhet: Permanent Black, 2009), 368. For a balanced critique of the national-exceptionalist and potentially "historicist" dimensions of this characterization, see Vasant Kaiwar, The Postcolonial Orient. The Politics of Difference and the Project of Provincialising Europe (Leiden: Brill, 214), 194-212.

52. Chatterjee, The Politics of the Governed, 39, 38. While Chatterjee briefly mentions the possible Gramscian inspiration behind his own use of the term "political society" (51), he does not explore further the substantially opposed meanings they ascribe to the same formulation, based upon their very different understandings of the political nature of civil society itself.

53. Alberto Moreiras, The Exhaustion of Difference: The Politics of Latin American Cultural Studies (Durham, NC: Duke University Press, 2001), 53, 296.

54. For an opposed argument regarding the irreducible difference between conditions of subalternity in "colonial and metropolitan theatres," see Gyan Prakash, "Subaltern Studies as Postcolonial Criticism," American Historical Review 99, no. 5 (1994): 1480.

55. Guha, Dominance without Hegemony, xii. 
56. $Q 1, \S 48,59$.

57. $Q 25, \S 5,2287$. A text: $Q 3 \S 90,372-73$.

58. Partha Chatterjee, Lineages of Political Society. Studies in Postcolonial Democracy (New York: Columbia University Press, 2011), 1-26.

59. Pandey, "The Subaltern as Subaltern Citizen," 4736.

60. Gyanendra Pandey, A History of Prejudice: Race, Caste, and Difference in India and the United States (Cambridge: Cambridge University Press, 2013), 27.

61. Gyanendra Pandey, ed., Subaltern Citizens and Their Histories. Investigations from India and the USA (New York: Routledge, 2010), 5.

62. Ibid., 6.

63. Pandey, A History of Prejudice, 9.

64. Étienne Balibar, Citoyen sujet et autres essais d'anthropologie philosophique (Paris: PUF, 2011).

65. Giorgio Agamben, Homo Sacer: Sovereign Power and Bare Life (Stanford: Stanford University Press, 1998), 18.

66. Veena Das, "Subaltern as Perspective," in Subaltern Studies VI, Writings on South Asian History and Society (New Delhi: Oxford University Press, 1989).

67. Alf Gunvald Nilsen and Srila Roy, ed., New Subaltern Politics. Reconceptualizing Hegemony and Resistance in Contemporary India (New Delhi: Oxford University Press, 2015).

68. Massimo Modonesi, Revoluciones pasivas en América (Mexico City: ITACA, 2017).

69. Wendy Brown, Undoing the Demos. Neoliberalism's Stealth Revolution (New York: Zone Books, 2015).

\section{Author Biography}

Peter D. Thomas teaches political philosophy and the history of political thought at Brunel University London. He is the author of The Gramscian Moment: Philosophy, Hegemony and Marxism (Brill, 2009) and coeditor of Encountering Althusser (Bloomsbury, 2012), In Marx's Laboratory (Brill, 2013), and The Government of Time (Brill, 2017). Recent publications include “"The Modern Prince': Gramsci's Reading of Machiavelli" (History of Political Thought) and "The Plural Temporalities of Hegemony" (Rethinking Marxism). 